\title{
현대 한국사찰 체험문화 대중화 연구
}

- 템플 스테이 프로그램 개발과 구성의 방향을 중심으로

각정(정해성)

\section{국문초록}

템플 스테이는 참가자가 일정기간 사찰에 머물면서 한국불교문화를 누구 나 체험을 할 수 있게 사찰 산문을 개방하여 스님들의 수행생활을 공개하 고 사찰에서만 전해 내려오는 각종 수행과 생활방식을 체험프로그램으로 제공하는 일이 바로 템플 스테이다. 참가자는 템플 스테이를 통해 스님들 의 일상을 체험하며 한국불교의 전통문화를 이해하고 친밀감을 느낄 수 있다.

현재 각 운영사찰에서 활발하게 운영되고 있는 템플 스테이에 특이한 점 
은 해를 거듭할수록 최초 참가자 비율이 많아지고 있다는 것이다. 이것은 템플 스테이의 프로그램에 변화가 없고 같은 프로그램을 진행하고 있음을 시사한다. 재 참가율을 높이기 위해서는 참가자의 다양한 욕구변화와사회 적 분위기에 알맞은 프로그램의 개발과 구성이 필요하다.

템플 스테이 참가자의 다양한 이해를 현재의 템플 스테이 프로그램이 만족시키기에는 무리가 있으며 단일사찰에서 해소하기에 어려움이 있다. 때문에 한국불교문화사업단에서 템플 스테이 운영에 적합한 사찰을 직접 현장답습 하여 운영사찰에 알맞은 프로그램을 개발하여 제공하는 것도 바 람직하다.

예로 지리적 접근성이 좋은 도심이나 쉽게 접근할 수 있는 사찰의 경우 에는 일반적인 여가상품으로서의 성격을 띤 프로그램을, 반대로 접근성이 떨어지는 사찰의 경우 역사가 깊고 일정규모의 인원을 수용할 수 있는 사 찰은 불교적 색채를 강화한 불교문화 체험프로그램을, 사찰의 규모가 작아 소규모의 인원만을 수용할 수 있는 사찰의 경우에는 명상이나간화선 중심 의 정신수양 프로그램을, 불교역사나 문화가 깃든 사찰에서는 '강좌가 포 함된 프로그램을 운영하면 좋을 것이다.

그리고 정부의 각 부처 정책과제 중에서 템플 스테이와 연계 가능한사업 이 다수 있다. 이외 부부갈등 해소 및 용서를 통한 가족문제를 해결함으로 써 템플 스테이에 대한 긍정적인 평가를 축적하고 나아가 각종 기업 및 사 회단체 연수 등을 통해 템플 스테이가 학교, 직장, 기타 사회단체에서도 널 리 확산시켜 나가야 할 것이다. 템플 스테이는 시민사회라는 사회적 지반 위에 뿌리를 내릴 때 안정적인 성장을 지속할 수 있다. 그런데 아직까지도 템플 스테이의 주요 고객은 중산충이며, 그 문호가 서민층이나 사회적 약 자가 참가할 수 있을 정도로 열려 있지는 않다.

또한 외국인 참가자들을 위해서는 전 세계의 수행센터와 정보교류는 물 
론 인적 교류체계를 확립하고 한류 열풍처럼 템플 스테이를 한국문화를 대표하는 국제적인 문화프로그램으로 발전시켜 나갈 수 있는 방안을 모 색해야 한다.

주제어 : 템플 스테이, 템플 스테이 프로그램, 템플 스테이 체험, 한국불교문화.

\section{I . 들어가는 말}

템플 스테이는 참가자가 일정기간 사찰에 머물면서 한국불교문화를 누구나 체험을 할 수 있게 사찰 산문을 개방하여 스님들의 수행생활을 공개하고 사찰에서만 전해 내려오는 각종 수행과 생활방식을 체험프 로그램으로 제공하는 일이 바로 템플 스테이다. 참가자는 템플 스테이 를 통해 스님들의 일상을 체험하며 한국불교의 전통문화를 이해하고 친밀감을 느낄 수 있다.

현재 각 운영사찰에서 활발하게 운영되고 있는 템플 스테이는 2002 년 한 일 월드컵이라는 전 세계적 문화 이벤트를 계기로 한국을 세계 에 알리려는 국가적 요구와 불교문화의 대중화라는 불교계의 요구가 절충되는 과정에서 탄생하였다. 특히 당시 외국인들의 숙박문제를 해 결하려는 국가적 과제에 더하여 외국인들에게 직접 한국불교 전통문 화를 체험할 수 있는 기회를 제공한 것이 그 시작이었다. (각정, 2010) 2002 년에 33 개 운영사찰에 내국인 1,299 명과 외국인 1,259 명이 참가 
하여아래의 표와 같이 12 년 동안 꾸준하게 운영사찰이 증가하였고, 참 가자 역시 꾸준히 증가하였다. 2013년까지의 통계를 보면 889개 사찰 에서 총 124 만 여명이 참가하여 양적으로나 질적으로 성장하였으나, 외국인은 약 $13 \%$ 참가한 것으로 조사되어 외국인 참여는 저조하였다.

\section{〈표1〉 템플 스테이 참가자 현황}

\begin{tabular}{|c|c|c|c|c|c|c|c|c|}
\hline \multirow{3}{*}{ 차수 } & \multirow{2}{*}{\multicolumn{2}{|c|}{ 운영사찰 수 }} & \multicolumn{6}{|c|}{ 참가자 순인원 } \\
\hline & & & \multicolumn{2}{|c|}{ 내국인 } & \multicolumn{2}{|c|}{ 외국인 } & \multicolumn{2}{|c|}{ 합계 } \\
\hline & 개수 & 증가율 & 내국인 & 증가율 & 외국인 & 증가율 & 순인원 & 증가율 \\
\hline 2002년 & 33 & - & 1,299 & - & 1,259 & - & 2,558 & - \\
\hline 2003년 & 16 & $-51.5 \%$ & & - & & - & 3,755 & $46.8 \%$ \\
\hline 2004년 & 36 & $125.0 \%$ & 33,695 & - & 3,207 & - & 36,902 & - \\
\hline 2005년 & 41 & $13.9 \%$ & 45,932 & $36.3 \%$ & 6,617 & $106.3 \%$ & 52,549 & $42.4 \%$ \\
\hline 2006년 & 50 & $22.0 \%$ & 61,417 & $33.7 \%$ & 9,497 & $43.5 \%$ & 70,914 & $34.9 \%$ \\
\hline 2007년 & 74 & $48.0 \%$ & 68,119 & $10.9 \%$ & 13,533 & $42.5 \%$ & 81,652 & $15.1 \%$ \\
\hline 2008년 & 87 & $17.6 \%$ & 92,694 & $36.1 \%$ & 20,106 & $48.6 \%$ & 112,800 & $38.1 \%$ \\
\hline 2009년 & 102 & $17.2 \%$ & 121,494 & $31.1 \%$ & 19,399 & $-3.5 \%$ & 140,893 & $24.9 \%$ \\
\hline 2010년 & 109 & $6.9 \%$ & 152,937 & $25.9 \%$ & 20,045 & $3.3 \%$ & 172,982 & $22.8 \%$ \\
\hline 2011년 & 118 & $8.3 \%$ & 187,937 & $22.9 \%$ & 24,550 & $22.5 \%$ & 212,487 & $22.8 \%$ \\
\hline 2012년 & 109 & $-7.6 \%$ & 146,640 & $-22.0 \%$ & 23,752 & $-3.3 \%$ & 170,392 & $-19.8 \%$ \\
\hline 2013년 & 114 & $4.6 \%$ & 164,853 & $12.4 \%$ & 21,743 & $-8.5 \%$ & 186,376 & $9.5 \%$ \\
\hline 합계 & \multicolumn{2}{|c|}{889} & \multicolumn{2}{|c|}{$1,077,017$} & \multicolumn{2}{|c|}{163,708} & \multicolumn{2}{|c|}{$1,240,725$} \\
\hline
\end{tabular}

그리고 템플 스테이 최초로 참가한 내국인 참가 회수를 살펴보면〈 표 2 〉의 비율은 $80.7 \%$, 〈표 3 〉은 $78.3 \%$, 〈표 4 〉는 $73.6 \%$ 로 평균 $77.5 \%$ 이 다. 그리고 재 참가율에서도 횟수가 많을수록 재 참가자의 숫자가 적다. 또 특이한 점은 해를 거듭할수록 최초 참가자 비율이 많아지고 있다 
는 것이다.

외국인의 경우는 최초참가자가 $91.1 \%, 2$ 회는 $6.0 \%, 3$ 회는 $1.4 \%, 4$ 회

이상이 $1.5 \%$ 로 나타났다. (불교문화사업단, 2013)

이것은 템플 스테이의 프로그램에 변화가 없고 같은 프로그램을 진행 하고 있음을 시사한다. 재참가율을 높이기 위해서는 참가자의 다양한 욕 구변화와사회적 분위기에 알맞은 프로그램의 개발과 구성이 필요하다.

〈표2〉 2012 템플 스테이 내국인 참가자의 참가 회수

\begin{tabular}{c|c|c}
\hline 항목 & 빈도(명) & 백분율(\%) \\
\hline 1회 & 3,549 & 80.7 \\
\hline 2회 & 418 & 9.5 \\
\hline 3회 & 158 & 3.6 \\
\hline 4회 & 66 & 1.5 \\
\hline 5회 이상 & 114 & 2.6 \\
\hline 무응답 & 93 & 2.1 \\
\hline 합계 & 4,398 & 100.0 \\
\hline
\end{tabular}

※ 한국불교문화사업단, 「2012년 템플 스테이 고객만족도 조사결과 보고서」, p.8

〈표3 2013 템플 스테이 내국인 참가자의 참가 회수

\begin{tabular}{c|c|c}
\hline 항목 & 빈도(명) & 백분율(\%) \\
\hline 1회 & 13,282 & 78.3 \\
\hline 2 회 & 1,934 & 11.4 \\
\hline 3회 & 729 & 4.3 \\
\hline 4회 & 305 & 1.8 \\
\hline 5회 이상 & 713 & 4.2 \\
\hline 합계 & 16,963 & 100.0 \\
\hline
\end{tabular}

※ 한국불교문화사업단, 「2013년 템플 스테이 고객만족도 조사결과 보고서」, p.18 
〈표4〉 템플 스테이 내국인 참가자의 참가 회수

\begin{tabular}{c|c|c}
\hline 항목 & 빈도(명) & 백분율(\%) \\
\hline 1회 & 394 & 73.6 \\
\hline 2 3회 & 94 & 17.5 \\
\hline $4 \sim 5$ 회 & 24 & 4.5 \\
\hline 6회 이상 & 23 & 4.3 \\
\hline 합계 & 535 & 100.0 \\
\hline
\end{tabular}

※ 각정, 2011, 「제1회 템플 스테이 논문 공모전」, p.87

또한 템플 스테이는 불교가 지향하는 인류 보편의 가치를 전달하는 사회기구이자 제도적 장치이다. 특히 불교의 사회적 기능이 무지, 탐 옥, 증오 등 삼독을 버리고 불성과 만나서 본래의 사회성을 회복하는데 있다면, 그러한 이념을 실현하는 템플 스테이는 삶의 궁극적 의미 혹은 내적 의미를 반성하고 체험하는 기회를 제공해 주고 전체구성원이 상 생하는 사회를 건설하는데 기여할 것이다. (유승무, 2014)

즉, 우리는 '좋은 사회'와 '좋은 사람(구성원)'을 만드는 것이고 칠불통 계에 내포된 이념은 인류가 추구하는 보편적 가치이고 그러한 점에서 종교, 인종, 성별, 연령, 계층 등을 초월하여 누구에게나 기회가 개방되 어 있다. 이와 동일한 원리로, '개인의 행복'과 '세계의 평화를 위한 프 로그램을 개발이 필요하다. 


\section{II. 템플 스테이 프로그램 위상과 중요성}

\section{1. 위상}

2009년 이후 템플 스테이는 국내외적으로 명실상부한 불교문화 체험 프로그램으로 인식되었고, 이에 우선 국가는 제 3 차 관광 진흥 5 개년 계 획(2009-2013년)에서 또 다시 템플 스테이 활성화 계획을 수립하였다. 동시에 템플 스테이는 $\mathrm{OECD(2009)}$ 에서 국가브랜드위원회(2010)가 선 정한 '대한민국을 대표하는 10대 아이콘'으로 자리 잡고 '세계의 성공적 인 5대 문화관광 상품'으로 선정되었으며, 이로서 '시즌 2'가 시작 되었 다. 그것은 웰빙(well-being)과 힐링(healing)에 대한 관심이 고조되어, 한국불교문화사업단에서는 2013년 템플 스테이 슬로건을 '나를 위한 시간 행복 여행'으로 지정하고 '템플 스테이 2'를 시작하였다.

이처럼 일반대중의 욕구에 발맞추어 대중화된 템플 스테이를 통해 참여자들은 우리나라 사상의 토대가 되는 한국불교의 역사 - 문화를 접하고, 사찰주변의 아름다운 경관을 감상함으로써 일상생활에서 받 는 스트레스 속에서 정신적 휴식과 여유를 얻고 있으며, 이에 언론도 주목하고 있다. 템플 스테이가 21세기 물질문명 시대에도 풍요로운 정 신에 행복이라고 소개하고(문화일보, 2007. 5. 23.), 템플 스테이 체험 담을 소개하는 등 불교신도가 아닌 다른 종교인들도 심심찮게 참여한 다고 소개하고 있다. (한국일보, 2006. 12. 12.)

최근에는 부부갈등 치유에는 부부와 함께 명상을 하면 30 년 묵은 체 증이 쑥 내려간다고 소개하고(중앙일보, 2014. 10. 20), 식(食) 아닌 약 (藥)이라고 사찰음식을 소개하면서 '몸 면역력 키우고 마음도 맑게...' 라며 소개하고 있다(문화일보, 2014. 10. 30.). 특히 한국사찰음식이 이 
탈리아 세계슬로푸드대회에서 인기몰이를 하였다고 소개하였다.(연 합뉴스, 2014. 11. 5.)

템플 스테이는 '심신 단련에 딱'TV · 컴퓨터 없어 디지털 디톡스, 108 배로 근력 강화(중앙일보, 2014. 11. 17.), '나 안의 참 나를 만나는 프로 그램-자기를 되돌아보는데 많은 시간과 비용을 들이지 않고도 할 수 있는 여행(경남신문, 2014. 12. 19.), 숲속 걷기 · 명상으로 심신 치유, 사찰 주변 명소 역사 배우기도(한국일보, 2015. 1. 8.) "토털힐링캠프'가 마련돼 비상한 관심을 모으고 있다-스님, 심리학자, 음식전문가, 정신 과의사, 요가전문가, 한의사 등이 입체적으로 제공하는 캠프라고 소개 하고 있다.(세계일보, 2015. 1. 9.)

\section{2. 중요성}

제 3 차 관광 진홍 5 개년 개획에서의 사업목적은 우리 고유 문화자원을 한국을 대표하는 체험관광 상품으로 육성하는 사업내용으로, 전통사 찰을 한국 고유문화 관광 상품으로 개발하고, 참선 · 예불체험 등을 체 험관광 상품으로 활용하는 것이다. 즉 전통사찰의 템플 스테이 활성화 로 한국 전통문화 체험의 장으로 활용하는 것이다.

사업의 목적으로, 한국 전통 문화 특화형 테마숙소시설의 개발확대 사업은 불교문화 체험형, 고유 전통숙박시설 개발확대 지원, 현재 참 선과 체험위주로 이루어지고 있는 템플 스테이 프로그램 다양화, 불 교문화에 기초한 구연 프로그램 개발 및 공연장 설치지원 등으로 되 어 있다.

그런데 템플 스테이의 성공여부는 궁극적으로 이러한 프로그램에 
대한 참가자의 체험 만족도에 달려있다. 이와 관련하여 한국불교문화 사업단에서 2012년 템플 스테이 고객만족도 조사 결과서 ${ }^{127}$ 를 보면 내 국인의 경우 프로그램의 전반적인 만족도는 평균 4.39점(5점기준) 매 우 높게 나타났다. 성별로는 남성은 4.32점, 여성은 4.43점으로 여성이 더 만족한 것으로 나타났으며, 연령대별 만족도에서는 50대가 4.48점 으로 가장 높게 나타났다. ${ }^{128)}$

외국인의 경우 전반적인 만족도는 평균 4.38점으로 매우 높게 나타 났으며, 성별로는 남성이 4.41점, 여성이 4.36점으로 매우 높게 나타났 고, 연령대별로는 20 대가 4.45점으로 가장 높게 나타났다. ${ }^{129)}$

2013년 템플 스테이 고객만족도 조사미)에서 내국인 만족도는 평균 4.24점 ${ }^{131)}$ 으로 높게 나타났으며, 성별에서는 남녀 모두 4.24점으로 동 일하게 나타났고, 연령대 만족도는 40대와 50대가 동일하게 4.37점으 로 높게 나타났다. ${ }^{132}$

외국인의 경우 만족도 평균은 4.22점 ${ }^{133)}$, 성별로는 여성이 4.24점으 로 남성 4.18점보다 높게 나타났다. 연령별 비교에서 40대가 4.31점으 로 가장 높게 나타났다. ${ }^{134}$

127) 2012년 6월 15일 1013년 3월 31일까지 템플 스테이 참가자 내국인 4,398명, 외국인 참가자 548 명 표본조사. 편의상 2012년으로 표시함.

$128) 10$ 대가 4.22점, 20대는 4.44점, 30대와 60대 이상은 4.43점, 40 대는 4.38점으로 나타남.

129) 10 대가 4.43점, 50대가 4.29점, 30대가 4.28점, 60대 이상은 4.09점으로 나타남.

130) 2013년 6월 2013년 12월까지 템플 스테이 114 개 운영사찰 중 84개 운영사찰 참가자 내국인 17,176 명, 외국인 참가자 1,561 명을 유효 표본으로 분석.

131) 프로그램 유익성이 4.26점, 진행자와 참가자간 소통이 4.24점, 프로그램 시작 시 전체일정 및 내 용안내가 4.23점으로 나타남.

132) 60대가 4.35점, 30대가 4.30점, 20대가 4.20점, 10대가 4.06점으로 나타남.

$133)$ 진행자와 참가자간 소통이 4.29점, 프로그램 시작 시 전체일정 및 내용안내가 4.23점, 프로그램 유익성이 4.14점으로 나타남.

134) 30대가 4.29점, 20대와 50대가 4.22점, 60대가 4.21점, 10대가 4.01점으로 나타남. 
그리고 2010년도 조사에서 재 참가의향을 가진 참가자의 비율은 90\%였고 ${ }^{135)}$, 2013년 불교문화사업단 고객 만족도 조사에서 내국인의 경우 재 참가의향이 $83.2 \%$, 타인 추천의향은 $85.6 \%$, 외국인의 재 참가 의향은 $82 \%$, 타인 추천의향이 $88.8 \%$ 로 나타났다.

이상의 결과는 템플 스테이가 체험자들에게 정신적 위안과 편안함 을 제공하고 있다는 것을 의미한다.

템플 스테이 내국인 참기동기 1,2,3위를 보면 2012년 조사에서는 '휴 식/일상의 재충전', '도시로부터의 일상탈출' '불교문화에 대한관심' 순 으로 전체의 $50 \%$ 를 넘었고 ${ }^{130}, 2013$ 년 조사에서는 '휴식/일상의 재충 전', '자아성찰과 심신안정', ‘도시로부터의 일상탈출' 순으로 역시 전체 의 $50 \%$ 를 넘었다. ${ }^{137}$

외국인 참가동기를 보면 2012년 조사에서는 '한국 전통문화에 대한 관심,' '불교문화에 대한 관심, '호기심' 순으로 전체의 $50 \%$ 가 넘었으며 ${ }^{138}, 2013$ 년 에서도 순위는 같고 $60 \%$ 가 넘었다. ${ }^{139}$

위와 같이 내국인의 참가동기 1 위가 ‘휴식/일상의 재충전'이고, 외국 인의 참가동기 1 위는 '한국 전통문화에 대한관심'이다. 이렇게 볼 때 템 플 스테이 프로그램은 참가동기에 충족될 수 있는 프로그램의 구성이

135) 재참여 및 추천의향 실태조사(2010, 각정).

\begin{tabular}{c|c|c|c}
\hline \multirow{2}{*}{ 구분 } & 재참여 의향 & 추천 의향 \\
\hline \multirow{3}{*}{ 재참여 및 추천의향 } & 있다 & $90.8(481)$ & $94.5(501)$ \\
\cline { 2 - 4 } & 없다 & $9.2(49)$ & $5.5(29)$ \\
\cline { 2 - 4 } & 합계 & $100.0(531)$ & $100.0(530)$ \\
\hline
\end{tabular}

주 1 : 백분율, 괄호안은사례수.

2 : 변수에 무응답이 존재하여 합이 537 이 아닌 경우도 있음

136) 휴식/일상의 재충전 $26.1 \%$, 도시로부터 일상탈출 $14.7 \%$, 불교문화에 대한 관심 $10.5 \%$

137 ) 휴식/일상의 재충전 $30.9 \%$, 자아성찰과 심신안정 $12.5 \%$, 도시로부터 일상탈출 $11.3 \%$

138 ) 한국 전통문화관심 $23.0 \%$, 불교문화관심 $17.1 \%$, 호기심 때문에 $16.8 \%$.

139) 한국 전통문화관심 $25.6 \%$, 불교문화관심 $18.7 \%$, 호기심 때문에 $18.4 \%$. 
중요하다.

역으로 참가동기를 유발할 수 있는 프로그램의 구성도 필요하다고 본다. 그리고 템플 스테이의 지원금에 대한 우리사회 일각의 비판 ${ }^{140)}$ 을 고려하면 템플 스테이의 공익성을 담보함으로서 정당성이 강조될 수 있는 프로그램의 구성도 중요하다고 본다.

\section{III. 템플 스테이 프로그램의 실태와 문제점}

템플 스테이는 보통 1박 2일로 이루어지며, 아래의 그림은 한국불교문 화 사업단에서 제공하는 산사의 하루 일정이다.

- 03:00 도량석과 기상

새벽 3시, 주위는 여전히 어둠이다. 하지만 지금부터 산 사의 하루는 시작된다.

- 04:30 새벽예불

도량석이 끝나는 것과 동시에 작은 소리로부터 큰 소리 로 점점 높이 울리며 종을 친다. 이어 북, 범종, 목어, 운판 의 사물(四物이 차례로 울리며 모든 대중 이 큰 법당에 모여 경건하게 새벽예불을 올린다.

- $06: 30$ 아침공양 울력

- 11:30 사시마지와 점심공양

- 15:00 자유정진 포행

140) 타종교인 및 국회의원. 
사시불공과 점심공양을 마치면 산사에도 여유가 찾아온 다. 그러나 진정한 여유는 내 안에 있는 것으로 사찰에서 의 포행은 수행의 일부다.

- 17:00 저녁공양 및 저녁예불

산사의 저녁은 세속보다 빨리 찾아온다. 오후 5시경이면 저녁공양을 한다. 공양 후에는 잠시 쉬고 법당에 모여 저 녁예불을 모신다.

- 22:00 수행체험 및 취침

예불이 끝난 뒤각 수행처에서는 예정된 수행프로그램을 진행한다. 그리고 대부분 오후9시면 잠자리에 든다.

\section{1. 템플 스테이 프로그램 실태}

\section{1) 기본 프로그램 ${ }^{141}$}

\section{(1) 사찰안내}

사찰순례는 단순히 불교사원을 방문해 보는 것이 아니라 살아 숨 쉬 는 불교의 전통과 문화를 느끼고 배우는 불교 전통문화 순례의 길이 될 것이다. 사찰의 구조와 건축, 조각, 공예, 불화, 단청 등 각종 문화 재들은 부처님의 가르침과 민족의 전통을 오롯이 간직하고 있기에 사 찰순례를 통하여 이러한 의미와 아름다움을 음미해 보는 경험을 해보

141) 한국불교문화사업단 홈페이지 참조하여 정리. 
는 것이다.

\section{(2) 참선}

참선은 선정에 참입 한다는 뜻으로 곧 본마음, 즉 참 나를 밝히는 작업 으로 한국불교의 중심이 되는 수행법이다. 선은 마음을 통일하여 잡념 을 일으키지 않는 것이며, 그리하여 진정한 자기의 참모습으로 돌아가 는 것이다. 그것을 깨달음이라고도 하고, 본성을 본다고 하여 견성이 라고 한다. 실질적으로 외국인 참가자들의 기대치가 가장 높은 프로그 램이다. 이는 외국인 관광객들이 참선을 뉴에이지와 연관된 명상과 착 각하는 일이 많다.

\section{(3) 스님과의 차담}

부처님의 가르침에 의거한 수행자인 스님과 함께 대화를 나누는 시간 이다. 부처님의 가르침에 따라 현대를 살아가는 목적과 구체적인 방법 등에 대한 질문과 대화를 하는 시간이다. 살아가면서 궁금했던 점이나 혼자서 고민하고 풀지 못하였던 모든 것들을 부처님의 가르침에 의거 한 수행자인 스님과 함께 나누고 해답을 강구해보는 시간은 새로운 삶 의 이정표가 될 것이다.

다도는 불교의 수행인 동시에 한국의 전통문화로서 소개된다. 다기 (茶器)를 준비하여 차를 마시기까지의 과정이 일정한 규칙에 따라 진 행된다. 그러나 다도 직후 스님과의 대화 시간이 이어지기 때문에 본래 목적했던 불교 체험이라기보다는 템플 스테이를 마무리하는 휴식 혹 은 전통문화 맛보기 등의 가벼운 경험으로 인식될 수 있다. 


\section{(4) 발우공양}

발우는 절에서 스님이 쓰는 밥그릇이며 '적당한 양을 담는 밥그릇’이란 뜻이 들어 있다. 스님들이 발우로 행하는 식사를 발우공양이라 한다. 발우공양은 단순히 밥을 먹는 그런 식사예법이 아니라, 수행의 한 과정 으로 행하기 때문에 법공양이라고도 한다.

발우공양은 템플 스테이 일정 중 가장 강조되는 것이다. 불교의 식사 법을 의미하는 발우공양은 그 자체로 가장 기본적인 수행이라 하여 엄 격한 규칙에 따라 진행된다.

(5) 예불

예불은 템플 스테이의 종교관광적 측면을 가장 단적으로 드러내주는 일정이다. 참가자들은 자신의 종교와는 상관없이 불교의 의례를 경험 하게 된다. 따라서 참가자들은 이 관광이 매우 종교적임을 의식하게 되 며, 여타의 유희적 관광과 템플 스테이를 구분할 수 있게 된다.

\section{(6) 108 배}

절을 한다는 것은 아상에 찬 나를 낮추고 불성을 가진 상대를 높이는 것이다. 일 배씩 절하는 숫자마다 나를 참회하고 108번뇌가 소멸되며, 새로운 출발을 염원하는 것을 뜻하며 불교에서 가장 기본이 되는 참회 와 발심의 구체적인 행동이다. 나를 비워야만 새로운 것을 담아낼 수 있듯이 절하는 과정 매 순간이 무념의 상태에서 불성을 만나는 체험의 시간이 될 것이다. 


\section{(7) 연꽃 만들기}

연꽃 모양의 등을 연등이라 하며, 보통 얇은 종이를 이용하여 연꽃잎 을 손으로 한잎 한잎 접어 풀로 붙이는 과정을 거쳐 형형색색의 아름 다운 연등이 만들어 진다. 연꽃은 더러운 진흙 속에서도 더러움에 물 들지 않고 아름답고 깨끗하게 피어나는 것이, 마치 무지와 어두움 속에 쌓여 있는 중생의 그 마음을 닦아 부처의 성품을 드러내어 부처가 되는 것을 상징하기 때문이다.

\section{2) 운영(체험) 프로그램142)}

현재 운영사찰의 홈페이지에 소개된 프로그램을 살펴보면, 참가자의 다양한 욕구에 맞추어 아래와 같이 다양한 프로그램을 만들었으나 운 영에는 프로그램과 불일치되는 프로그램을 진행하거나 운영자체를 하 지 않는 사찰도 있었다.

대부분의 사찰에서는 기본적인 시간(예불, 공양시간, 취침)만 따르 도록 하고 자유롭게 휴식을 취할 수 있는 프로그램이었다.

명상이나 불교예절과 문화를 영어로 진행하는 영어 프로그램143), 심 신 수련을 위해 산이나 계곡을 트래킹(등반과 하이킹의 중간 형태로

142) 중앙승가대학교 2학년 2학기 “템플 스테이 운영의 실제”과목 과제물로 2014년 110 개 운영사찰 을 2014년 10월에 수강생이 분담하여 운영사찰 담당자와 직접통화 하였다. 조사내용은 공개된 홈페이지 프로그램과 실제 운영하는 프로그램 비교, 불교문화사업단에 보고된 템플 스테이 지 도법사(담당자)확인, 홍보방법, 참가금액, 참가자 수용인원, 애로사항(문제점), 전화 응대 친절 도 이다. 수강생의 전화조사는 템플 스테이 운영 및 지도법사로서의 역량을 키우기 위하여 실 시하였다. 110 개 운영사찰 중에서 106 개 사찰이 조사되었다.

143) 무각사, 축서사, 홍법사. 
걷는)하는 프로그램 ${ }^{144)}$, 각종 장 담그기와 사찰음식을 만드는 프로그램 ${ }^{145)}$, 신심단련을 위한 체험과 공연을 볼 수 있는 선무도, 건강한 육체를 위한 선 체조, 선 요가, 선 기공 프로그램146), 유적지나 문화재를 탐방하 거나 불교문화(사찰의 구조와 건축, 조각, 공예, 불화, 단청 등)를 관람 하는 프로그램147), 명사를 초청하여 강연을 하거나 워크샵처럼 진행하 는 프로그램 ${ }^{148)}$, 직접 작품을 만들어볼 수 있는 양초, 염색, 한지공예, 판 화(목판), 도자기 만들기 프로그램149), 사찰의 분위기와 맞는 콘서트 프 로그램 ${ }^{150)}$, 서당처럼 한문을 배우는 프로그램 ${ }^{151)}$, 지역의 농가와 연계한 팜 스테이 프로그램 152 , 자연경관을 감상하면서 여유롭게 포행(걷기)하 기와 숲속에서 명상하거나 달빛과 별빛을 받으면서 명상 하는 프로그 램153), 녹차 잎을 직접 따고 차를 만드는 프로그램154), 사찰주변의 생태 와 접목하여자연의 아름다움을 느끼며 산나물, 약초 등 동 · 식물을 관 찰할 수 있는 생태체험 프로그램 ${ }^{155)}$, 지역축제와 연계한 프로그램150) 등 다양한 형태로 템플 스테이 프로그램을 운영하고 있다.

\footnotetext{
144) 갑사, 내소사, 대흥사, 선암사, 수덕사, 쌍봉사, 옥천사, 현덕사.

145) 대원사(보성), 보경사, 선석사, 영평사.

146) 골굴사 : 선요가 - 선기공 - 선무도, 구룡사 : 띠아난따 요가, 대원사 : 선체조, 은해사 : 요가.

147) 봉녕사, 불국사, 서광사, 숭림사, 신륵사, 신흥사(완도).

148) 백련사(가평), 천은사, 통도사.

149) 제주 관음정사 : 도자기, 구룡사 : 염색 - 도자기 · 한지공예, 명주사 : 목판화, 불갑사 : 한지공 예 · 도자기, 약천사 : 양초· 서각.

150) 금산사 : 짝수달 마지막 토요일, 기림사 : 가을음악회, 마곡사.

151) 부석사.

152) 금산사 : 모내기 · 벼 배기, 지장정사 : 마늘, 고구마, 딸기 등.

$153)$ 광명사, 구룡사, 금산사, 낙산사, 대승사, 도리사, 묘적사, 반야사, 범어사, 봉녕사, 보경사, 삼화 사, 선운사, 신훙사(속초), 신흥사(화성), 용화사, 자비선사, 장육사, 천은사, 화계사(서울).

154) 개암사, 금산사, 기림사, 대원사(보성).

$155)$ 구룡사, 대광사, 대승사, 대원사(산청), 반야사, 백련사(가평), 백련사(강진), 부석사, 심원사, 약 천사, 용연사, 용화사, 한국문화연구원, 증심사.

156) 금산사 : 김제지평선 · 전주국제영화제· 전주발효엑스포.
} 


\section{3) 모범 프로그램의 분석}

\section{(1) 선무도}

골굴사의 템플 스테이는 선무도 중심의 프로그램은 템플 스테이가 한 국문화의 특수한 정신문화를 담고 있다는 인식이 특히 외국인 참가자 들에게 긍정적인 영향을 미친 것으로 판단된다.

선무도 프로그램의 성공요인은 경주라는 지리적 인지도와 선무도 라는 공연과 체험의 엔터테인먼트, 지역 관광지와의 연계가 좋고 시 설과 환경이 쾌적하며 외국인들에게는 개인 프라이버시가 보장된다.

\section{(2) 사찰음식}

최근 한류가 한국(전통)문화에 대한 호의적 이미지를 형성하고 사찰음 식의 세계화가 일종의 한류로 성장하면서, 템플 스테이에 대한 외국인 의 관심이 고조되고 있고, 국내에서도 건강을 위한 식단에 관심이 사찰 음식 프로그램에 좋은 평가를 받고 있다. 이처럼 사찰음식 템플 스테 이를 한국문화를 대표하는 국제적인 문화 프로그램으로 발전시켜 나 갈 수 있는 방안을 모색해야 한다. 이와 관련하여 사찰음식을 템플 스 테이와 접목시킨 것은 매우 바람직해 보인다.

\section{2. 템플 스테이 프로그램 문제점}

참가자들은 '불교문화를 알고 싶은' 욕구를 충분히 충족시키면 불교에 대한 이해는 물론 이미지도 좋아지겠지만, 반대로 프로그램이 기대를 충족시켜 주지 못하면 실망을 하게 되고 심지어는 불교에 대한 믿음을 
철회할 수도 있다. 그렇기 때문에 프로그램은 템플 스테이의 성공여부 를 판가름하는 결정적인 요소이다.

템플 스테이 프로그램은 운영사찰에서 참가자들에게 제공하는 체험 내용을 체계화하고 조직화 한 것을 말한다. 그렇기 때문에 예로 '발우 공양과 같은 동일한 일상생활 프로그램도 '템플 스테이용' 발우공양 프 로그램은 출가수행자의 대중 방에서 이루어지는 발우공양과 그 의미, 형태, 내용, 순서 및 전반적인 분위기 등에서 반드시 동일할 필요가 없 다. 또한 예불 프로그램의 경우도 참가자들에게는 신도들에게 요구되 는 신심이 전제되어 있으리라고 기대할 수 없다. 그러므로 기본프로그 램도 차등을 두어 초심자 프로그램과 불자들을 위한 심화된 프로그램 으로 구분해야 할 것이다.

운영사찰의 환경적 요인이나 특색을 살린 특화된 프로그램을 운영 하면 한국전통불교문화가 생생하게 살아 움직이는 이미지를 확립할 수도 있을 것이다.

그러므로 참가자들이 가볍게 불교문화를 접할 수 있는 여가나 관광 이 강조된 프로그램, 불교역사에 관심이 있는 참가자들을 위해 불교역 사 강좌가 포함된 프로그램, 불교문화나 역사는 아니지만 문화혼융으 로서의 프로그램, 생태환경에 관련된 프로그램, 지역의 축제와 연계한 프로그램, 소외계층을 위한 프로그램 등이 활성화 된다면 많은 이들의 관심과 참가로 이어지게 될 것이다.

특히 소외계층을 위한 프로그램은 대승불교의 보살정신을 사회적으 로 실천할 수 있는 계기가 될 것이다.

정부에서 제 3 차 관광 진흥 5 개년 개획에서 또 다시 템플 스테이 활 성화계획을 수립한 것은 우리 고유의 문화자원을 한국을 대표하는 체 험관광 상품으로 육성하고자 하는 것이다. 이에 걸맞은 다양한 프로그 
램의 부재와 정부의 각 부처 정책과제 중에는 템플 스테이와 연계 가능 한 사업이 다수 포함되어 있다. 이러한 정부부처와의 연계된 프로그램 이 없다는 것이 아쉽다.

\section{IV. 템플 스테이 프로그램 개발의 구성}

\section{1. 템플 스테이 프로그램 개발의 구성요소}

\section{1) 여가 및 관광 157$)$}

템플 스테이는 여가상품과 관광 상품, 또한 불교문화의 속성을 동시에 갖고 있으며, 소비되어 사라지기보다는 체험되어 남는 복합적 특성을 갖는다. 이런 특성은 문화산업론 158 , 여가사회론, 포스트모던 여가론, 특수목적관광(SIT) 등을 통해 이해할 수 있다.

템플 스테이를 일종의 상품으로 이해하는데 적절한 이론은 문화산 업론이다. 마르크스의 이론모형 속에서 문화현상을 분석하는 문화산 업론의 입장에서 보면 여가시간 동안 이루어지는 모든 소비활동은 자 본주의 경제체제라는 토대와 무관하지 않다. '현대적 여가의 본질은 적 나라한 이윤동기를 문화적 형태들로 이전하는 것을 목표로 대량복제 를 통해 생산된 여가상품의 소비일 뿐이다'(Adorno, 1975:13). 그러나 템플 스테이는 이윤동기가 지배하는 여가활동이 아닐 뿐만 아니라 불 교 문화적 특성 때문에 소외를 강화하기 보다는 그 극복을 추구할 수

157) 각정, 「현대 한국 불교문화의 대중화 연구,」 pp. 170 174를 정리 함.

158) 문화산업론에 대한 자세한 이론적 논의는 Story(1994)를 참고. 
있는 여가활동이다. 따라서 문화산업론적 시각으로는 비자본주의(혹 은 탈자본주의)적 성격을 갖는 템플 스테이를 충분히 이해할 수 없다.

문화산업론과 대조적인 이론적 입장을 지니고 있는 여가사회론, 포 스트모던 여가론, SIT(Special Interest Tourism) 등도 템플 스테이와 관 련지어 검토할 수 있는 주요한 이론적 자원들이다.

템플 스테이가 비자본주의적(탈자본주의적) 특성을 갖고 있다는 점 을 강조할 경우, 일종의 탈산업사회론(탈산업주의론)이라 할 수 있는 여가사회론을 피해 갈 수는 없다. 여가사회론은 산업화로 인한 물질적 풍요가 개개인의 가처분 소득을 증대시켰을 뿐만 아니라 여가시간의 증대와 개인의 자유를 신장시킴으로써 여가사회가 도래했다는 입장을 갖고 있다(Parker, 2002). 템플 스테이와 소외된 노동은 서로가 서로를 필요로 하는 공존공생의 관계를 지니고 있는 것이다. 이렇게 볼 때, 여 가가 노동을 대체하는 것으로 이해하는 여가사회론 역시 템플 스테이 를 이해하는데 적합하지 않다.

여가를 포함한 문화를 노동과 이분법적으로 사고하는 또 하나의 지 적 흐름은 포스트모더니즘에서도 찾아 볼 수 있다. 포스트모던 여가론 은 이성적으로 볼 때 실제가 아님에도 불구하고 인간의 감성을 자극하 는 기호나 모사가 우리의 삶을 지배하는 현상을 설명함으로써 주목을 받고 있는 지적 흐름을 통칭하는 개념이다. 이러한 관점에서 보면 포스 트모던 쇼핑몰이나 여가센터와 같은 현대적 여가상품은 노동이나 생 산에 불구한 '시뮬라시옹(simulation)'에 불과하다 ${ }^{159}$. 그렇기 때문에 포 스트모던 여가론도 템플 스테이를 온전히 설명할 수 없다.

한편 최근 급속히 팽창하고 있는 생태관광이나 축제 등과 같은 특수

$159)$ 포스트모더니즘과 여가의 관계에 대해서는 Rojek(2002)을 참고. 
한 체험형관광에 관심을 갖는 학자들은 템플 스테이를 이른바 특수목 적관광(SIT)의 일종으로 간주하려는 유혹을 받기 쉽다(민웅기, 2007). 특수목적관광을 유형화한 도울링에 따르면 특정종교나 문화유산은 SIT의 대표적인 문화상품이다(Dowling, 1993). 이렇게 볼 때, 불교 전 통문화 혹은 불교 문화유산을 여가의 화상으로 활용하고 있는 템플 스 테이는 일견 SIT로 해석될 여지를 상당부분 포함하고 있다.

위에서 살펴보았듯이 문화산업론은 여가현상을 자본주의의 문제로 환원하고 있기 때문에 비자본주의적 성격을 갖는 템플 스테이를 충분 히 설명하지 못하는 한계를 가진다.

이에 새로운 이론으로 엘리아스(Elias, N.)의 과정사회학(혹은 결합 체사회학)이론이다. 실제로 엘리아스는 여가를 삶의 긴장 및 위기와의 연속선 혹은 상호의존선 상에서 이해하고 있으며, 스포츠와 여가를 그 의 독특한 문명화과정 이론으로 이해하였다(.Mennell, 1992: 140 147) 엘리아스는 사회학이론의 전통적 이분법 즉 구조와 행위의 대립을 지양하고 양자의 상호의존성과 그 변화과정을 장기지속의 관점에서 해석할 것을 제안했고(Krieken, 1998), 그러한 관점에서 여가현상을 독 창적으로 해석해 낸 바 있다(Elias, 1986). 그러나 엘리아스의 결합체 개 념만으로는 세계체제, 국가의 정치경제제도, 특수한 종교문화, 개인의 행위 등 사회단위적 차원에서의 다차원적 요소들 사이에서 실제로 발 생하는 상호의존성이나 매우 이질적이고 모순적인 다양한 요소들 사 이의 상호의존성과 그로부터 파생된 템플 스테이를 충분히 이해할 수 는 없다. ${ }^{160)}$

160) 엘리아스 연구자로 알려진 로버트 크리켄은 엘리아스의 결합체 개념이 행위주체(actor)와 행위 주체의 관계에만 초점을 맞춤으로서, 제도와 제도의 관계는 물론 제도와 행위주체의 관계 등을 충분히 고려하지 못했다고 비판한 바 있다(Krieken, 1998). 
템플 스테이를 여가와 관광으로써 성과를 분석한 연구는 - 방문외 국인의 사찰체험관광 행동분석(유승무 외, 2002), 문화관광축제 육성 방안(김철원 외, 2002), 관광자원으로서의 불교사찰에 관한연구(고현 동, 2002), "템플 스테이 : 여가상품인가, 불교문화인가?(각정 외, 2007), 현대적 여가활동으로서의 관광에 관한연구(민웅기, 2007), 한국사회의 '또 하나의' 여가 트랜드-불교적 여가활동을 중심으로(유승무, 2009), 사 찰관광자원에 관한 연구(황현철, 2011), 여가경험으로서의 템플 스테 이 참여가 초· 중등학생의 자아존중감과 사회성 및 정서에 미치는 영 향(전병관 외, 2013), 체험관광으로서 템플 스테이 관광만족에 관한 연 구(안해연, 2012), 템플 스테이의 체험요소가 체험의 기억과 즐거움 및 만족도에 미치는 영향(박도윤, 2014) 등이 있다.

\section{2) 문화혼용}

앞에서 템플 스테이가 2002년 한일월드컵을 계기로 전통적으로 출가 자만의 총체적 기구였던 한국의 사찰에 외국인이 거주할 수 있도록 개 방하면서 시작되었고, 이는 한국불교의 전통이라는 측면에서는 일종 의 파격적이었음을 밝혔다. 그렇다면 이러한 파격을 가능케 한 힘은 어 디에서 나왔을까? 무엇보다도 한국불교를 세계에 알릴 수 있는 기회를 가질 수 있다는 합리적 계산이 '전통고수'의 입장을 압도했기 때문이다. 그렇다면 왜 한국불교는 자신을 세계에 알리는데 지대한 관심을 가질 수밖에 없게 되었는가? 이를 설명할 수 있는 불교적 개념이 바로 '시절 인연인데, 이는 세계화라는 시대정신이 템플 스테이를 가능하게 한 원 인(遠因)이었음을 시사한다.

세계화가 문화적 측면에서 야기하는 현상은 크게 두 가지로 나누어 
지는데, 그 하나는 문화적 공존, 대화, 혼융의 현상이고 다른 하나는 문 화갈등 현상이다. 즉 '세계화 시대의 문화적 거버넌스(governance)는 양면적이다. 한편으로는 문화 간의 공존이 일어나 세계주의적인 문화 적 복합정체성의 시대가 열리고 있는가 하면, 다른 한편으로는 기존의 본원적 문화적 정체성을 고수하려는 신부족 주의가 동시에 나타난다. ( 임혁백 외, 2004를 참고)'

템플 스테이는 문화 간 공존 및 혼융현상의 전형이다. 개항 이후 지 금까지 약 100 여 년 동안 한편으로는 전통문화(유교 및 불교문화)를 강 하게 고수하면서, 다른 한편으로는 물질주의적 서구문명을 적극적으 로 수용해 온 한국사회에서 문화적 혼융은 그다지 어색한 현상도 아니 다. 일찍이 로버트슨은 일본의 종교문화를 혼융성(syncretism)이란 개 념으로 표현한 바 있는데(Robertson, 1992: 94), 이러한 개념은 오늘날 한국사회의 발전에 대한 사회학적 설명에도 유효할 것으로 판단된다.

문화적 혼융(혹은 혼융문화)의 관점에서 볼 때, 템플 스테이는 동양 문화와 서양문화, 물질문화와 정신문화, 여가상품과 불교문화, 상품성 과 탈상품성 등이 복합적으로 만나 혼융된 문화이다. 또 다른 관점에 서 말하면 템플 스테이는 국가의 지원, 불교계의 적극적 동의, 현대인 의 노동소외 및 정체성 혼란과 그 극복의 욕구 등이 화학적 반응을 일 으킴으로써 탄생한 비의도적 산물이다. 물론 템플 스테이의 성격은 시 간의 흐름에 따라 또 다른 성격이 부가되기도 하고 기존의 성격 중 일 부가 탈각되기도 할 것이다. 이는 템플 스테이에는 다양한 만남이 중 중무진(重重無盡)으로 연관되어 있음을 의미한다. 즉 템플 스테이에는 동양과 서양의 만남뿐만 아니라 세계사회와 국가, 국가와 종교, 국가와 개인, 종교와 개인, 개인과 개인, 개인과 문화, 개인과 상품 등 가시적 요인뿐만 아니라, 그 가시적 요인과 우리가 인식하지 못하는 많은 비가 
시적 요인사이의 만남(혹은 관계)도 존재한다. 한마디로 템플 스테이 는 연기(緣起)의 산물이다.

템플 스테이를 불교문화인 종교적 시각으로 연구한 논문은 전통문 화콘텐츠로서의 템플 스테이 개발에 관한 연구(김영훈, 2007), 한국 종 교성지의 현대적 의미(허남진, 2010), 현대 종교문화 현상으로서 템플 스테이 연구(배금란, 2010), 세계의 중심상징과 성지순례: 종교 현상적 접근(김용표, 2010), 불교무형문화유산의 문화콘텐츠 개발과 활용 방 향에 대한 연구(이재수, 2010), 복지문화 프로그램의 일환으로서 템플 스테이 활용방안(권경임, 2011), 현대종교문화 현상으로서 템플 스테 이 고찰(배금란, 2011)한일 종교관광의 전개와 최근 동향: 불교와 종교 관광을 중심으로(임순록, 2013) 등의 연구가 있다.

\section{3) 불교역사 및 문화}

삼국시대에 불교가 전래된 이래, 역사 속에서 불교는 각 시대의 요구 에 맞게 그 성격을 변화시키면서 한국의 전통문화이자 주요 정신문화 로 자리 잡았다. 신라시대에는 그 시대의 요구에 따라 국가적 불교, 생 (소)의 불교, 약동의 불교로 변화하였다. 이는 진호국가의 사상으로 나 타났으며 백고강좌개설, 사천왕사의 건립, 팔관재회 건수(虔修) 등으 로 구체화되었다.

또 화랑도정신으로서 고승들이 직접 화랑도의 교도선상에 나서기도 하였다. 고려시대에는 거란과 몽고의 침입을 물리치기 위해 경판을 조 각하는데 불교계는 공을 들였다. 현종 2년(1011년)에 거란의 내침을 물 리치기 위해 고려장경판을 조각하였고, 고종 23년(1236년)에는 몽고군 을 물리치기 위해 15년에 걸쳐 팔만대장경을 완성시켰다. 
이처럼 불교문화는 시대의 요구에 맞춰 자신의 모습을 변화시켜왔 고, 그 과정에서 팔만대장경, 직지심체요절, 석굴암과 불국사 등 한국 을 대표하는 수많은 문화유산들은 후대에 남겼다.

불교는 오랜 세월동안 한국사회의 주요 종교로 자리 잡아왔으며 수 많은 문화유산을 남겼고, 정신적 가치를 제공하여 왔다. 비록 조선시 대 숭유억불 정책에 의해 대중들의 삶의 터전에서 밀려나 산속에서 수 행하는 산중불교로 변화되기도 하였지만, 이런 악조건에서도 민간에 서 여전히 불교는 일반대중들의 의례를 담당하였고 그들의 삶과 죽음 의 문제에 답을 해주는 정신적 가치 제공자로서의 역할을 수행하였 다. 즉 불교적 삶의 양식은 여전히 대중들의 문화의 한 부분이었다. 각정 2010)

템플 스테이를 불교역사, 문화로 연구한 논문은 - 전통문화콘덴츠로 써의 템플 스테이 개발에 관한 연구(김영훈, 2007), 불교무형문화유산 의 문화콘덴츠 개발과 활용 방향에 대한 연구(이재수, 2010), 한국불교 문화 체험의 현대적 양상 연구(배금란, 2011), 템플 스테이가 마음치유 에 미치는 영향(서용석, 2014) 등이 있다.

\section{4) 생태환경}

최근에 ‘생태문화(生態文化)'라는 용어가 많이 쓰이고 있다. 이 용어의 개념의 범위나 특성이 정립되지 않았지만, 어휘적으로 분석하면 '자연 생태와 문화유산'과 '생태적 문화'로 구분할 수 있는데, 사찰의 생태문 화는 사찰이라는 특수한 종교 공간 안에서 어우러진 생태적인 요소와 역사문화적인 요소를 두루 함축해 일컫는 말이다(2010, 김재일).

산중의 사찰은 스님들의 수행공간인 동시에 산의 풀과 나무, 벌레와 
짐승들이 더불어 살아온 생명의 터전이다. 사찰 생태기행은 비교적 관 찰이 용이한 식물부터 시작하여 조류와 곤충, 어류 그리고 동물의 순으 로 각기 산 속숲에 어떻게 터를 잡고 살아가는지 등을 살펴 볼 수 있다.

생태환경으로 연구한 논문은 - 템플 스테이 사찰의 자연체험을 위한 조경적 과제(홍광표, 2006), 템플 스테이 참가자와 사찰방문자를 위한 휴식공간의 설치(주경, 2005), 불교생태학에 기초한 템플 스테이 프로 그램모형연구(연희경, 2008) 등이 있다.

\section{2. 템플 스테이 프로그램의 구조}

현재의 프로그램의 구조 중 기본일정을 보면 03 시부터 22시까지 19시 간으로 일정이 너무 길다. 한국불교문화사업단의 만족도조사에서 참 가동기 1 위가 '휴식/일상의 재충전' 때문에 템플 스테이에 참가한 동기 와는 상반된다. 19시간 중에 쉬는 시간도 포함되어 있지만 불자가 아닌 참가자들에게는 피곤함을 줄 수 있으므로 초심자를 위한 시간배정과 불자들을 위한 시간 배정을 이분화 하는 것이 바람직할 것이다.

그리고 기본 프로그램을 보면 '사찰안내', '참선', '스님과의 차담', '발 우공양', '예불', '108배', '연꽃 만들기’ 등으로 불교색채를 너무 강조한 면 이 있다. 체험프로그램에서도 '영어', '트레킹' '강연', '만들기(양초, 염 색, 한지공예, 판화, 도자기)', '콘서트', '생태체험, '축제와 연계'한 프로 그램 외에는 불교적 색체를 띄고 있다. 앞의 모범프로그램의 '선무도', 사찰음식'프로그램은 불교문화 이면서도 참가자들에게 새로운 체험을 하는 프로그램이어서 참가자들에게 좋은 반응을 얻는 것이다.

기본 프로그램도 참가자들의 욕구와 운영사찰의 특색을 살린 것을 
포함하여 진행하면 좋은 프로그램의 구조가 될 것이다.

휴식형 템플 스테이의 구조를 보면 '예불', '공양', ‘취침'시간만 정하 고 나머지 시간의 프로그램이 없는 것은 참가자들에게 불교의 이미지 를 이상하게 비춰질 수 있다. 휴식형에 걸맞은 프로그램의 개발과 도 입이 필요해 보인다.

템플 스테이 '시즌2'의 새로운 브랜드 '아생여당(我生如堂)' ${ }^{161)}$ 은 단순 한 휴식이나 체험을 하던 기존 템플 스테이에서 한 걸음 더 나아가 개 인에게 필요한 맞춤형 경험을 제공하는 특화된 프로그램이기는 하나 앞서 운영된 프로그램과 대동소이한 구조로 느껴진다.

\section{V. 개발프로그램의 수정보완}

\section{1. 피드백(feedback)}

'feedback'은 본래 전기 공학상의 용어로 어느 동작의 결과를 원래의 동 작으로 되돌려 놓는 것을 뜻으로 피드백은 다양한 방법으로 구분된다. 평가적 피드백(evaluative feedback)은 어떤 과제를 얼마나 잘 수행했는 지에 관한 가치판단이 학습자에게 직접 전달될 때 일어난다. 교정적 피 드백(corrective feedback)은 해야 할 것과 해서는 안 될 것에 대한 정보

161) '아생여당'은 각각 위로, 건강, 비움, 꿈이라는 주제를 담은 아아(我我), 생생(生生), 여여(如如), 당당(堂堂) 등 4 개의 하위 브랜드로 구성됐다. '아생여당'은 13 개 사찰에서 운영되며, 각 사찰의 환경과 역량에 따라 특화된 프로그램을 제공한다. 아아(我我) 프로그램은 김제 금산사와 영동 반야사, 보은 법주사, 성주 심원사에서 운영하며, 생생(生生)은 동해 삼화사, 영암 도갑사, 양평 용문사, 산청 대원사에서 진행된다. 여여(如如)는 해남 미황사와 예산 수덕사에서, 당당(堂堂) 은 양양 낙산사, 인제 백담사, 용인 법륜사에서 운영한다. 
를 학습자에게 제공한다. 평가적 피드백과 교정적 피드백은 다시, '일 반적인 것과 구체적인 것, '긍정적인 것과 부정적인 것' ,학급, 집단 또 는 개인적인 것', '과제의 초점과 일치된 것과 일치되지 않는 것'으로 구 분할 수 있다. (한설희 외, 2003)

조사연구 피드백(survey feedback) 주요 목표는 전 조직에 걸쳐 정보 의 공유를 촉진하는 것이다. 오늘날 조사연구 피드백 방법은 360도 피 드백 기법의 기초가 되고 있다.

360 도 피드백이란 조직구성원 개인에게 그들의 상사, 동료, 그리고 부하들로부터의 정보를 제공하는 것이다. 이러한 피드백 반응은 그 개 인이 어디에서 일을 잘하고 있으며, 또한 어디에서 개선이 필요한 것인 가를 파악하게 해준다.(송계충 외, 2003)

이러한 조사연구 피드백은 보통 4단계로 진행된다. 첫째, 훈련된 변 화담당자의 지도하에 최고경영자는 사전계획을 세우고, 누구를 조사 하여야 하는가와 무슨 질문을 할 것인가를 결정한다. 둘째, 변화담당 자는 조사연구 설문지를 조직구성원 모두에게 배포한다. 셋째, 변화담 당자는 자료를 범주화하고 요약한다. 그것을 최고경영층에 제시한 후 집단모임을 개최하여 설문지에 응답한 모든 사람들이 결과를 알도록 한다. 넷째, 피드백 정보를 입수한 집단은 조사연구를 토의하기 위해 모임을 개최한다.

그렇기 때문에 템플 스테이의 프로그램은 이러한 모든 과정을 피드 백 하여 프로그램을 수정, 보완해야 할 것이다. 


\section{2. 변화의 반영}

참가자들은 늘어난 여가시간을 단순히 유흥에 소비하지 않고 보다 충 실하고 의미 있는 시간으로 보내기 위해 적극적으로 자신의 관심사에 맞는 네오웰빙(neo well-being)프로그램을 찾고 있다.

즉, 참가자들은 단순한 휴식을 추구하지 않고 자아성찰과 새로운 문 화체험이라는 목적을 가지고 참여하고 있으므로 템플 스테이문화가 참가자들과의 거리감을 줄일 수 있는 방향으로 변화될 필요성이 있으 며, 사회와 참가자들의 요구에 대응할 수 있는 프로그램으로 그 발전방 안을 모색해야 할 것이다.

이러한 일련의 모든 문제 또는 현상을 바로 잡은 뒤 개선하고 피드 백을 통해 반복해서 점검하여 반영해야 재 참가율이 높아질 것이다.

\section{VI. 나가는 말}

템플 스테이 참가자의 참가동기처럼 다양한 이해를 현재의 템플 스테 이 프로그램이 만족시키기에는 무리가 있으며 단일사찰에서 해소하기 에 어려움이 있다. 때문에 한국불교문화사업단에서 템플 스테이 운영 에 적합한 사찰을 직접 현장답습 하여 운영사찰에 알맞은 프로그램을 개발하여 제공하는 것도 바람직하다.

예로 지리적 접근성이 좋은 도심이나 쉽게 접근할 수 있는 사찰의 경우에는 일반적인 여가상품으로서의 성격을 떤 프로그램을 운영하 여 종교와 무관하게 일반인들이 쉽게 접근할 수 있는 템플 스테이로, 반대로 접근성이 떨어지는 사찰의 경우 역사가 깊고 일정규모의 인원 
을 수용할 수 있는 사찰은 불교적 색채를 강화한 불교문화 체험프로그 램을 제공할 필요가 있다. 또한 사찰의 규모가 작아 소규모의 인원만 을 수용할 수 있는 사찰의 경우에는 명상이나간화선 중심의 정신수양 프로그램이 자아성찰의 기회를 갖고 마음의 휴식을 찾으려는 이들에 게는 좋을 것이다.

불교역사나 문화가 깃든 사찰에서는 '강좌'가 포함된 프로그램으로 불교문화와 역사를 깊이 있게 알 수 있게 하는 프로그램을 운영하면 문 화포교로서 일반대중들에게 불교에 대한 이미지와 관심을 불러일으킬 수 있으며, 기존 불자들에게는 교육프로그램의 일환으로도 손색이 없 을 것이다. 더불어 지역의 역사 및 문화재와도 연계한 프로그램을 운영 한다면 지역사회에서도 일익을 담당할 수 있을 것이다.

이러한 다양한 프로그램을 각각의 지역(市·道)에 운영사찰을 두어 참가자들이 쉽게 접근할 수 있게 한다면 참가자 자신의 관심에 따라사 찰을 쉽게 결정하고 체험하면 그에 따른 만족도도 현재보다 높아질 것 이다. 운영사찰의 입장에서도 타 사찰과는 특화된 프로그램을 홍보할 수 있으며 여건에 맞는 프로그램은 운영도 수월해질 것이다.

그리고 정부의 각 부처 정책과제 중에서 템플 스테이와 연계 가능한 사업이 다수 포함되어 있고 그 연계사업을 실현하기 위해서는, 정부와 의 정치적 관계가 불가피하다. 중앙 정부부처의 농림부, 환경부, 보건 복지부, 노동부, 여성가족부 지방정부의 정책적 과제 및 정책적 사업, 연수교육 등과 연계하는 것이다. 예로 2012년 정부의 각 부처의 사업 중 템플 스테이와 연계 가능한 정책과제를 구체적으로 적시해 보면 아 래와 같다.

농림축산식품부의 경우 한식세계화지원 사업으로 2012년 220억, 2013년 192억으로 인프라구축, 한식전문 인력양성, 한식당 경쟁력강 
화, 한식홍보 등의 사업을 수행하는 바, 특히 사찰음식 템플 스테이의 경우 이 사업과 연계할 수 있을 것이다. 환경부의 사업 중에서, 환경교 육 강화사업으로 청소년 환경교육프로그램 운영, 환경체험 교육프로 그램 등이 있고, 생태관광 자원이용 기반사업으로 생물다양성 보전과 지역경제 활성화 동시도모, 탐방, 체험시설 건립, 프로그램 개발, 해설 사 양성 등이 있다. 어린이 건강 종합대책 추진사업으로 어린이 활동 공간 및 어린이용품 조사, 아토피 센터 건립 등의 사업에 템플 스테이 가 정책적 연계방안을 찾을 수도 있을 것이다.

그 밖에도 보건복지부의 자살예방 및 지역정신보건 사업과 비행청 소년 교정사업, 노동자의 정신적 고통을 치유하는 사업이나 여성가족 부의 가정폭력 가해자 교정치료 프로그램 운영사업, 청소년 가출예방 전문프로그램 위탁 사업 등이 템플 스테이가 적극적으로 연계하여 사 업을 진행할 수도 있을 것이다. 그럼에도 불구하고 아직까지도 정부의 특정 부처와 연계사업은 활발하게 이루어지지 않고 있으며, 지방정부 나 지방자치단체의 지원과 역할은 상대적으로 미미할 뿐만 아니라 재 정적/정책적 지원과 같은 실질적인 지원은 이루어지지 않고 있다. 그 렇기 때문에, 무엇보다도 앞에서 제시한 중앙정부의 정책과제들 중 연 계 가능한 정책과제에 보다 적극적인 관심과 참여가 요청된다.

나아가 지방정부 역시도 중앙정부의 정책과제들 중 일부를 수행할 수밖에 없다는 점과, 그리고 템플 스테이가 지역적 차원에서도 커다란 공익성을 담보하고 있다는 점을 고려한다면, 교구본사나 단위사찰 차 원에서 지방정부 및 자치단체의 정책적 과제들과 연계할 수 있는 사업 에 적극적으로 참여해야 한다. 그리고 지방공무원의 연수교육 프로그 램들을 적극적으로 유치하여 지방정부와의 정치적 관계를 수립함으로 써 재정적 지원이나 다양한 정보를 확보하는 등 실질적인 지원을 유도 
할 필요가 있다.

대 자본주의 사회적 환경 속에서 인간의 모든 활동은 자본으로부터 결코 자유롭지 않다. 템플 스테이도 예외가 아니다. 템플 스테이가 유 지되고 발전되어가기 위해서는 안정적인 재정확보 및 재정확대가 필 수적이다. 그리고 이를 위해서는 템플 스테이가 가치를 생산하고 그것 이 수요자들에게 판매되어야 한다. 개별 소비자는 체험상품을 구매할 것이고, 중앙정부나 지자체는 템플 스테이의 공익적 가치를 구매할 수 도 있을 것이다.

또한 생산과정에서는 일정한 생산비용이 수반되기 때문에, 템플 스 테이의 물적 토대에 대한 면밀한 비용 및 편익분석이 항상 수반되어야 한다. 특히 시설 확충 및 개선, 각종서비스의 질적 향상, 프로그램의 다 양화 및 전문화, 취약계층으로의 참가대상의 양적 확대와 같은 공익적 가치의 확대 등을 위해서는 템플 스테이의 재정 상태에 대한 점검이 상 시적으로 이루어져야 한다.

또한 템플 스테이가 국가, 정부의 각종 정책, 지방자치단체의 각종 사업은 물론 불교와 참가자 개인의 이해관심이 복합적으로 얽혀 있는 사업임을 감안할 때, 템플 스테이의 생산비용을 누가 어느 정도 부담할 것인가에 대한 과학적 분석과 그에 대한 사회적 합의가 요구된다. 그 리고 템플 스테이가 자립적 기반 위에서 장기적인 발전을 이어가기 위 해서는 재정적 자립방안을 적극적으로 고민하지 않을 수 없다. 특히 템 플 스테이와 기업연수 프로그램을 연계함으로써 템플 스테이와 기업 이 상생할 수 있는 방안을 적극적으로 모색할 필요가 있다.

이와 관련하여 우리는 하트스토밍(heartstorming) 프로그램을 전문 으로 하는 템플 스테이 프로그램도 새롭게 도입할 것을 적극 권장하고 싶다. 앞에서 기업과 템플 스테이의 연계방안을 언급했거니와, 템플 스 
테이에는 가족뿐만 아니라 학교 및 기업의 소집단이나 단체의 집단적 참가도 이루어진다. 또한 템플 스테이에 대한 긍정적인 이미지는 시민 사회를 통해 급속히 확산되는 경향이 강하다.

그렇기 때문에 부부갈등 해소 및 용서를 통한 가족문제를 해결함으 로써 템플 스테이에 대한 긍정적인 평가를 축적하고 나아가 각종 기업 및 사회단체 연수 등을 통해 템플 스테이가 학교, 직장, 기타 사회단체 에서도 널리 확산시켜 나가야 할 것이다. 템플 스테이는 시민사회라는 사회적 지반 위에 뿌리를 내릴 때 안정적인 성장을 지속할 수 있다. 그 런데 아직까지도 템플 스테이의 주요 고객은 중산충이며, 그 문호가 서민층이나 사회적 약자가 참가할 수 있을 정도로 열려 있지는 않다.

그러나 템플 스테이가 시민사회에 광범위하게 뿌리를 내리기 위해 서는 중산층 중심의 프로그램을 넘어서서 서민층이나 사회적 약자 층 을 위한 프로그램으로 확대되어야 한다. 따라서 향후에는 서민층이나 사회적 약자 층을 위한 템플 스테이를 계발하고 운영하려는 목적의식 적 노력을 경주해야 한다. (유승무, 2014)

비행청소년, 노동자, 실직자, 외국인 노동자, 탈북자, 미혼모, 노숙인 등을 대상으로 한 특수 템플 스테이 프로그램의 운영은 시민사회에서 템플 스테이의 위상은 물론

그 공익적 가치를 높이는데도 기여할 것이다.

정치가 시민사회의 압력으로부터 자유로울 수 없다는 점을 고려할 때, 템플 스테이가 시민사회의 각계각층에서 회자되는 것은, 중앙정 부 및 지방정부의 연계 가능한 정책과제에 적극적으로 참여할 수 있 는 정치적 기반 내지는 효과로 작용할 것이다. 특히 외국인 템플 스테 이 참가자들을 위해서는 전 세계의 수행센터와 정보교류는 물론 인적 교류체계를 확립하고 한류 열풍처럼 템플 스테이를 한국문화를 대표 
하는 국제적인 문화프로그램으로 발전시켜 나갈 수 있는 방안을 모색 해야 한다. 


\section{참고문헌}

- 각 정, 「현대한국 불교문화의 대중화 연구 : 선 수행, 연등축제, 산사음악회, 템플 스테이 중심 으로」, 중앙승가대학교 박사학위논문, 2010.

「템플 스테이 대중화 연구 : 참여효과를 중심으로」, 『제1회 템플 스테이 논문 공 모전』, 대한불교조계종 한국불교문화사업단, 2011.

- 김영훈, 「전통문화콘텐츠로써의 템플 스테이 개발에 관한 연구」, 복지행정연구 제23집, 안양 대학교복지행정연구소, 2007.

- 김철원 외, 『문화관광축제 육성방안』, 한국관광연구원, 2002.

- 대한불교조계종 한국불교문화사업단, 『2012 2013 템플 스테이 고객 족도 조사 결과보고서』, 대한불교조계종 한국불교문화사업단, 2013.

- 대한불교조계종 한국불교문화사업단, 『2013템플 스테이 고객만족도 조사 결과보고서』, 대한 불교조계종 한국불교문화사업단, 2014

- 민웅기,「현대적 여가활동으로서의 관광에 관한 연구」, 고려대학교 박사학위논문, 2007.

- 박선권, 『현대적 여가의 상태』, 르네상스, 2002.

- 서용석, 「템플 스테이가 마음치유에 미치는 영향」, 불교문예연구 2집, 동방대학원대학교 불 교문예연구소, 2014.

- 송계충 외, 『조직 행위론』, 경문사, 2003.

- 시사타임즈, 「템플 스테이, 스페인 산티아고에 우뚝 서다」, 2014년 9월 25일자.

- 유승무 외, 「방문외국인의 사찰체험관광 행동분석」, 『국제문화와 관광 · 경제』, 한 · 일 공 동주최 2002년 국제학술대회 발표논문집, 한국문화관광학회 · 일본홋가이도관광학회, 대구대 학교, 2002.

- _ 템플 스테이 : 여가상품인가, 불교문화인가?」, 논문집, 제12집, 중앙승가대학 교, 2007.

, 「한국사회의 ‘또 하나의' 여가 트랜드 : 불교적 여가활동을 중심으로」, 『불교 사상과 문화』, 제1호, 중앙승가대학교 불교학연구원, 2009. 
2014.

- 이재수, 「불교무형문화유산의 문화콘텐츠 개발과 활용 방향에 대한 연구」, 불교학보 제56집, 동국대학교불교문화연구원, 2010.

- 임혁백 외, 『세계화의 문화정치학』, 집문당, 2004.

- 전병관, 「여가경험으로서의 템플 스테이참여가 초 - 중등학생의 자아존중감, 사회성 및 정서에 미치는 영향」, 한국체육과학회지, 제22권 제6호, 한국체육과학회, 2013.

- 주경, 「템플 스테이참가자와 사찰 방문자를 위한 휴식공간의 설치」, 사찰조경연구 제11집, 동 국대학교부설사찰조경연구소, 2005.

- 한설희 외, 『워킹지도법』, 학문사, 2003.

- 황현철, 「사찰관광자원에 관한 연구」, 논문집, 제30집, 동부산대학교, 2011.

- 호광표, 「템플 스테이 사찰의 자연체험을 위한 조경적 과제」, 사찰조경연구 제 11 집, 동국대학 교부설사찰조경연구소, 2005 .

- Adorno, T. Culture Industry Reconsidered. New German Critique, no 6 Fall, Madison Wisconsin, 1975.

- Dowling, R. An Environmentally-based Planning Model for Regional Tourism Development. Journal of Sustainable Tourism 1, 1993.

- Elias, N. \& E. Dunning. Quest for Exitement: Sport and Leisure in the civilizing process. Oxford, Blackwell, 1986.

- Krieken, R. NORBERT ELIAS, N.Y. Routledge, 1998.

- Mennell, S. Nobert Elias: An Introduction. Blackwell, 1992.

- Robertson, R. Globalization: social theory and global culture. Sage, 1992.

- Rojek, C. 최석호 · 이진형 역, 『포스트모더니즘과 여가(Decentring Leisure: Rethinking Leisure Theory)』, 일신사, 2002.

- Story, J. 박모 역, 『문화연구와 문화이론(An Introductory Guide Cultural Theory and Popular Culture)』, 현실문화연구, 1999. 